\title{
THE TREND OF MODERN THOUGHT ${ }^{1}$
}

A A FIRST GLANCE, there would appear to be A something contradictory in the attitude of men nowadays on the subject of philosophy. It is the custom to disparage it as being productive of empty abstractions, and yet, at the same time, we find in quite a flourishing state a philosophic literature that stirs to enthusiasm a serious and numerous reading public. It is even remarked that statesmen and journalists, novelists and critics, eagerly take up subjects of philosophic import and are given credit for profound knowledge, though they deal with their material in a very cursory fashion.

This apparent contradiction is less evident if we consider that the mode of philosophizing in vogue at the present time is very different from that of the past. From a philosophy unrelated to life and science and claiming to find in pure reason all the elements and objects of its existence and development we turn away, regarding it, for the most part, as empty formalism, an artificial structure, a survival of scholasticism. We see in it only something that satisfies the mind, something that is worthless to those who, through contact with positive science and living reality, have acquired a sense of certainty. On the other hand, however, we extend an eager welcome to such philosophic thought as would seem to be the legitimate product of a collaboration between the mind and the things of the sen-

1 Authorized translation by Fred Rothwell. 
sible world, presenting itself as a sincere interpretation of science and life, not as a more or less ingenious and novel exegesis and combination of concepts worked out by philosophers of the past.

Our age is tired of a philosophy which claims to be selfsufficing, to nourish itself exclusively on its own substance. Rather does it demand one based on experience, on reality universally recognized as such, and on positive science. It demands an answer to such questions as the following: What is the world? What are we? How are we to act if we would play our part as human beings to the best of our ability?

Not by chance has philosophy, for some time past, seemed jealously bent on creating a sphere of its own and sufficing unto itself, apart from the science of the world of sense.

Ancient philosophers, Plato and Aristotle, for instance, regarded nature as susceptible of divinity, as herself more or less divine. Thus spirit, for the living of its own life, could rely on nature to summon her to itself. Its whole ambition, moreover, consisted in contemplating nature and finding in her the dominion of the eternal laws of reason -a dominion wherein it had a direct participation. With the advent of Christianity, however, nature underwent a change. Now, she is no more than an inert thing, wholly external to spirit, which created her ex nihilo. On this point, modern science is strangely at one with the JudaeoChristian religion, regarding nature as a crude machine wherein the eternally identical play of given and immutable material forces of itself produces all the phenomena of life, without there ever being room for a guiding thought.

How then can spirit, in its dealing with nature, find for itself an element of life and growth? To unite with 
nature would be to abandon and betray - to do away with -itself. On the other hand, by setting itself over against nature, spirit becomes distinctly conscious of what is proper to itself; it ensures for itself full liberty of action and of expression. The reduction of nature to principles that are anti-spiritual thus becomes for spirit, in so far as it escapes from them, the occasion of a new and powerful affirmation of its own distinctive life and originality.

Now, however, positive science, originally well pleased to explain by mechanical principles what are called external phenomena and respectful of the mystery which has seemed to envelop life and thought, has come to consideritself possessed of methods which enable it to subject to its own laws all forms of being without exception. Even the prodigiously increased dominion of mankind over things now makes the position of spirit with reference to nature appear in a new light. If man can modify the course of phenomena to this extent, then he is himself a phenomenon analogous to the rest. The sage of old, who could do no more than contemplate the eternal laws of being, was unable to feel himself one therewith as does the modern scientist who utilizes these laws. If wind and stream combine their action, then they are homogeneous forces. To control nature is to form part thereof.

Besides, where could spirit, apart from nature, find the fixed center, the principle of determination necessary for it to act, i. e., to be? In the past there was God. Modern criticism considers that in the concept of this God there existed many elements taken from nature herself, and that if an attempt is made to reduce it to its strictly suprasensible content, the concept is found to disappear. Amongst the main streams of contemporary thought, one of the strongest is that which turns us aside from the transcendental heaven of Epicurus-where it is not known if there are beings that toil and labor on earth-and leads us in 
the direction of the world of matter and temporal life, the object of science, the unapparent though sure basis of all our actions, desires and thoughts.

Such, then, at a time when we are enquiring if idealism is still a possible attitude to take up, are the terms of the problem: Given that spirit, so far as we know anything about it, is inseparaible from matter-a matter whose laws seem self-sufficing-can there yet be any free original life of spirit? Thus stated, it must be confessed that the problem appears singularly embarrassing.

In the first place, a grave concession is inevitable. It is by no means contradiciory, it is even far simpler, both logically and practically, to acknowledge that naturalism is right. It is possible to live a purely natural life, all that is needed is to give oneself up to the stream of events, not to resist the law of inertia, which, of itself, is realized in all that is.

Naturalism is one possible solution of the problem of human life; does it follow that it is the necessary solution? Suppose I refuse to be content with it, has any one the right to bring against me the reproach that my attitude is the expression of anything more than individual fancy? $*$ : * * *

The general idea that results from any investigation into contemporary thought may be formulated as follows: man is either less or more than, as a rule, he thinks himself to be.

If positive science alone is the standard of truth and possibility, man is less than he thinks he is. Individuality and personality, dignity and moral worth, the special rôle and higher destiny he persists in attributing to himself, are in contradiction not only with the actual conclusions, but also-a more serious matter-with the principles and methods, nay, with the very spirit of positive science. If science is the whole of true knowledge, we must see in the 
ideas on which human life is based something more than vain traditions which arise out of our predecessors' mistakes and ignorance.

But if science, of itself alone, is not the standard of the true, we must cease to set it up in opposition-as a judge from whom there is no appeal,--to spirit, which is bent on being and acting. Indeed, spirit aims at proceeding hand in hand with science, but what exactly is it that science imposes on it?

The difficulty of the question is found in the idea we form of the relation between science and spirit. Is science the expression of truth, an absolute per se, something stereotyped, which spirit can only consider passively from without and endeavor to describe? In that case, its postulates are, to us, the ultimate expression of truth; i. e., it is our duty to regard mechanical determinism and crude fac: as fundamental principles of Being. Any notion, then, that contradicts this mechanism, must be regarded as an illusion; nor is it difficult to show that this is the case witt. every principle that gives human life its form.

But perhaps science, as also language, art, civil laws, and religions, may be regarded not as something external to spirit but as an activity of spirit itself, so that even its deepest principles can be understood in their true meaning only as they refer to the thought on which they are built up and moulded. In that case there would exist nothing rigid or stereotyped, either from or for eternity. whether in science or in the objects around us. Spirit is life and creation. If scientific determinism is its product. it shows forth as a mould, whose consistence and rôle are not necessarily immutable. Scholasticism was simply the transformation of the living word into a dead and finished system. The substitution indeed for active thought, of scholasticism or of thought stereotyped by instruction, is in nature, for it is only an application of the natural and 
general law of habit. But it is not therefore necessary. Man may retain his activity and spiritual power by reacting against the sloth which renders him disposed to abdicate in favor of his habits.

Up to quite recently the human mind was fascinated by the clarity, the utility of science, and was dominated by it; at present it has a tendency to see that science is eminently life and activity, an urge in the direction of something better, and to restore science to that interior life whence it really proceeds.

This is equivalent to saying that human mind is determined to break through pure naturalism, and, while relying on nature, to seek after ends that transcend nature. What is it that determines these ends?

There is one system still favored by many philosophers, which is regarded as calculated to satisfy the mind; seeing that, whilst transcending naturalism, it endeavors to avoid the danger inevitable in individual predilections. That system is intellectualism.

Certainly this system frees us from the tyranny of the immediately given, granting a life other than that of the senses. But the principles it seeks behind sensible facts are still themselves facts in reality, rough impenetrable data which, when we try to discover their raison d'être, like the inert symbols that writing substitutes for living thought, maintain a solemn silence. The motto of intellec-

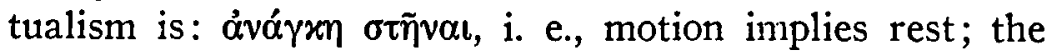
divisible implies the indivisible; the contingent implies the necessary and time implies eternity. An artificial mottc, impossible to imagine as capable of realization; for neither can the analysis of change lead to the immutable, nor can there be any intuition enabling us absolutely to grasp primary elements. Intellectualism represents the despondency of spirit retreating before an endless task and demanding rest as the price of its effort. This, however, 
reality refuses : it does not weary of creating, however man may weary of conceiving. Instead of its lite being only the mechanical gesticulation of a dead body, it really does live. Nobody has ever succeeded, a priori, in dictating laws to reality. We think erroneously, first observing what nature has done and then endeavoring to classify her productions with the object of discovering, if possible, some of her habits. Our knowledge, ever relative to the extent of our observation and our mental adaptation, remains under subjection to things, and we have no right to be shocked if, because things cannot be reduced to our abstractions, they demonstrate to us that they really are.

Passing then beyond both naturalism and intellectualism, we have to find a point of view which will maintain the reality and value of nature without plunging spirit therein, and will ensure the supremacy and activity of spirit whilst also recognizing its union with nature.

Eucken regarded Fichte's philosophy as indicating the path to be followed in solving the problem. According to Fichte, spirit, being essentially active, dominates everything, but its activity is exercised by means of nature and the intellect. So it is in the Fichtean sense that Eucken would build up the concrete idealism which he imagined contemporary thought to be seeking.

On the one hand he established the reality that is distinctive of spirit as life and potency of creation by basing it on the reality and originality of the all. Spirit wills to be in self and for self; now, according to its essence this existence cannot be something superior both to objectivity pure and simple-or existence for others-and to objective immutable thought, which so far is no more than an abstraction. Spirit is only if it acts. It is not a thing, something susceptible of acting; it is action and life itself. Everything within it unfolds, is opposed to inertia, generates, creates and engages in self-creation. 
On the other hand spirit does not function in a vacuum; its activity consists in reducing things to itself, in permeat-ing and spiritualizing them. It is not an addition to nature like Kant's freedom-noumenon; it is immanent therein, guiding nature's action, of which itself is essentially the prime author.

The new idealism then instead of being set up apart from science, art, religions, given realities, according to the dualistic conception, inds, in the given, the very matter by whose aid it endeavors to realize spirit.

Before the natural tendency of the creature to remain fixed in its mode of being and detach itself from creative spirit, its task is to react against this inertia and constantly to awaken life in the human soul by resolving it into its principle.

Des Menschen Tätigkeit kann allzuleicht erschlaffen, Er liebt sich bald die unbedingte Ruh.

Let us not leave to Mephistopheles the task of shaking man out of his natural sloth. The spirit of affirmation and creation is also movement and effort. It also is true action, for to deny and destroy is but to yield to the blind force of dissolution, which tends to drive things on in the direction of sheer annihilation or nonentity.

Eternal life is not a contradiction in terms if it is no more than the organization, by spirit, of matter that is infinite.

Nourished by science and the experience of practical life, the philosophic spirit, which is within us the most immediate expression of the universal spirit, is no simple efflorescence of given reality. It is reason, and at the same time faith and risk: ein Suchen und Versuchen, ein Wet- 
ten und Wagen. Knowledge, thought, the spoken word, are all necessary, as also is toil and effort after that which is uncertain. If the value of the intention remains whole and entire, whatever happens, the perfection of the product and its capacity for maintaining life can never be known until afterwards. The greatest creations are always those that call forth the greatest number ci new creations.

Emile Boutroux. 